Article

\title{
Energy Storage in Earth-Abundant Dolomite Minerals
}

\author{
Sesha Srinivasan ${ }^{1, * \mathbb{D}}$, Dominic Dodson ${ }^{1}$, Mc Ben Joe Charles ${ }^{1}$, Scott L. Wallen ${ }^{1}{ }^{\mathbb{D}}$, \\ Gary Albarelli ${ }^{1,2}$, Ajeet Kaushik ${ }^{1}{ }^{\circledR}$, Nicoleta Hickman ${ }^{1}{ }^{\circledR}$, Ganga Ram Chaudhary ${ }^{3}{ }^{\circledR}$, \\ Elias Stefanakos ${ }^{4}\left({ }^{-}\right.$and Jaspreet Dhau ${ }^{5}$ (i)
}

1 Department of Natural Sciences, Florida Polytechnic University, 4700 Research Way, Lakeland, FL 33805, USA; Dodson.Dominic@gmail.com (D.D.); charles042899@gmail.com (M.B.J.C.); swallen@floridapoly.edu (S.L.W.); galbarelli@floridapoly.edu (G.A.); akaushik@floridapoly.edu (A.K.); nhickman@floridapoly.edu (N.H.)

2 Florida Industrial and Phosphate Research Institute, 1855 W. Main St., Bartow, FL 33830, USA

3 Department of Chemistry, Center of Advanced Studies in Chemistry, Panjab University, Sector 14, Chandigarh 160014, India; grc22@pu.ac.in

4 Clean Energy Research Center, University of South Florida, 4202 E. Fowler Ave, Tampa, FL 33620, USA; estefana@usf.edu

5 Molekule Inc., 3802 Spectrum Blvd, Suite 143, Tampa, FL 33612, USA; jasdhau@gmail.com

* Correspondence: ssrinivasan@floridapoly.edu; Tel.: +1-863-874-8527

Received: 25 July 2020; Accepted: 20 September 2020; Published: 24 September 2020

Featured Application: Thermochemical energy storage via reversible calcination and carbonation in presence of dolomites.

\begin{abstract}
Dolomite, a calcium magnesium mineral $\left(\mathrm{CaMg}\left(\mathrm{CO}_{3}\right)_{2}\right)$, is considered an undesirable accompanying mineral in the phosphoric acid production process and, as such, large quantities of this mineral are available in Florida. This study is aimed toward the characterization of the high-concentration phosphatic dolomite pebbles (handpicked dolomites) received from the Florida Industrial and Phosphate Research Institute (FIPR) and investigate their feasibility for thermochemical energy storage (TCES). The chemical composition, structural and microstructural characteristics of commercial and handpicked dolomite minerals was studied using a variety of techniques such as X-ray Fluorescence (XRF), Fourier-transform infrared spectroscopy (FTIR), and an automated mineralogy Automated SEM-EDX Mineralogy (or automated scanning electron microscopy) with energy dispersive $\mathrm{X}$-rays spectrometer (SEM-EDX), which confirmed the phosphatic pebbles received contains dolomite $\left(\mathrm{CaMg}\left(\mathrm{CO}_{3}\right)_{2}\right)$ phase in a high percentage. Particle size and the surface area were measured using XRD and $\mathrm{N}_{2}$ adsorption, the Brunauer-Emmett-Teller (BET) methods. Thermogravimetric analysis (TGA) was used to determine the activation energy for the calcination and re-carbonation reactions of the dolomite pebbles in nitrogen $\left(\mathrm{N}_{2}\right)$ and carbon dioxide $\left(\mathrm{CO}_{2}\right)$ atmospheres at temperatures up to $800^{\circ} \mathrm{C}$. The present results exhibit, for the first time, the potential for using abundant, high phosphatic concentration dolomite possessing long-term cycling behavior for thermochemical energy storage applications in Concentrated Solar Power (CSP) plants.
\end{abstract}

Keywords: dolomite; thermochemical energy storage; calcination; carbonation; activation energy

\section{Introduction}

In a 1914 U.S. Geological Survey Bulletin, Van Kauwenbergh et al. [1] presented a detailed study of the minerology and chemistry of the phosphates mined in Florida, specifically Polk and Hillsborough counties of Central Florida. From this report, it was understood that the most uneconomical ingredient in the phosphate mineral matrix was the calcium-magnesium mineral $\mathrm{CaMg}\left(\mathrm{CO}_{3}\right)_{2}$, also known as 
earth-abundant "dolomite", with a purity of at least $60 \%$ occurring in combination with sand (Silica or quartz $\sim 30 \%$ ). The mining industry routinely terminates their mining process, when they encounter the dolomites or "dolostones", which are the major source of magnesium and are not favorable for phosphate fertilizer processing. The gypsum $\left(\mathrm{CaSO}_{4} \cdot 2 \mathrm{H}_{2} \mathrm{O}\right)$ stack is a potential US-EPA sustainability concern for the precipitation of the $\mathrm{CO}_{2}$ reaction on limestones (calcium carbonate or $\mathrm{CaCO}_{3}$ ) or dolostones $\left[\mathrm{CaMg}\left(\mathrm{CO}_{3}\right)_{2}\right]$ during the geological sequestration processes, as demonstrated by Garcia et al. [2]. The late Professor of Mineralogy and Geology at Amherst College, Frederic Brewster Loomis, published an e-book, "Field Book of Common Rocks and Minerals" [3], in which he discusses systematic approaches to identifying minerals and rocks using their physical and chemical properties, including the composition of minerals, and their classifications based on metals. The phenomenon of metamorphism in rocks and minerals have been widely analyzed and discussed by Kurt Bucher and Martin Frey [4].

The dolomites are not only difficult to remove from the gangue (phosphatic minerals) but also pose "environmental sustainability" issues due to their deposition in clay settling ponds around these counties. The magnitude of this problem is considered to be multifold if the future mining processes continue growing to other counties such as Manatee, Hardee, and DeSoto in the State of Florida. The problem of dolomite sedimentation (or stockpiling) in mining plants or clay settling ponds is unavoidable, if there is a depletion of mostly wanted "overburden" soil or economic phosphate ores which are the main source of the phosphorous and phosphorites for the fertilizer industry. The presence of the most troublesome magnesium oxide $(\mathrm{MgO})$-containing dolomites are a major hindrance in the manufacturing of "phosphoric acid" for diammonium phosphate (DAP) fertilizer production. The high magnesium content increases the sulfuric acid consumption, and, therefore, causes a lower production rate and yield of phosphoric acid $[5,6]$. All of these consequences could be eliminated by a process that utilized the wasted geological resource, dolomite.

High-temperature thermochemical energy storage utilizes reversible reactions that store energy in the chemical potential of the system. This type of energy storage process is thought to be critical for the on-demand energy production and penetration of concentrated solar power (CSP) into the grid. Current storage systems rely on molten salts, which have an operating temperature limit of $550{ }^{\circ} \mathrm{C}$ and, therefore, the CSP systems operate at that temperature. However, the CSP plants do have the potential to operate at higher temperature $\left(>600^{\circ} \mathrm{C}\right)$ if an alternative to molten salt is found [7]. A recent publication by Konstantinos Kakosimos et al. [8] studied the characterization of surface carbonates obtained from various regions of the Qatar peninsula and have shown promising potential for applications in $\mathrm{CO}_{2}$ capture and thermochemical energy storage. According to this report, dolomites have higher performance in terms of $\mathrm{CO}_{2}$ sorption and storage capacity when compared to calcite, $\mathrm{CaCO}_{3}$ [9-11]. In a long-term cyclic stability study, up to $27 \%$ thermal energy storage was demonstrated by Perlinger et al. in a groundwater aquifer, which was plausibly due to the presence of minerals (dolomites) [12]. Another vital use of dolomite in producing a most wanted chemical, magnesium sulfate heptahydrate $\left[\mathrm{MgSO}_{4} .7 \mathrm{H}_{2} \mathrm{O}\right]$ to its highest purity of $99.2 \%$ could be deployed in medical, textile, tanning and agriculture industries [13].

A multi-year research and development by the Southern Research Company, a Sun Shot initiative of the US Department of Energy, was recently demonstrated for high-temperature thermochemical energy storage systems with the Concentrated Solar Power facilities [14,15]. Such high-temperature thermochemical energy storage units are in demand due to the abundant availabilities of heat storage materials such as dolomite in the Central Florida's Phosphate mining sites $[16,17]$. The commercial potential for the thermochemical energy storage and its marketable share predicted to be for year 2020 is $\sim 147$ GW and for the year 2050, it is of the order of 1089 GW with energy storage cost assumed to be at least $15 \mathrm{USD} / \mathrm{kWhth}$. The data for the thermodynamic and kinetic dissociation of dolomites are unambiguously unknown until recently [18]. The role of crystal structure on $\mathrm{CO}_{2}$ capture by limestone derived $\mathrm{CaO}$ subjected to carbonation/re-carbonation/calcination cycles at $\mathrm{Ca}$-Looping conditions were reported in the seminal paper published by Valverde et al. [19]. The equilibrium for the thermodynamic dissociations of dolomite is governed by the two reactiond given in equations below [20,21]: 


$$
\mathrm{CaMg}\left(\mathrm{CO}_{3}\right)_{2} \leftrightarrow \mathrm{MgO}+\mathrm{CaO}+2 \mathrm{CO}_{2} \quad \sim>600^{\circ} \mathrm{C}
$$

High-temperature impregnation has been carried out on an alumina fabric and was thought to serve two purposes such as cumbersome-free calcination and carbonation looping [22] with a cyclic capacity increase. It has been shown that mechanco-chemical synthesis [23] offers a simple, efficient, and inexpensive tool for the synthesis of highly stable $\mathrm{CaO}$-containing sorbents for high-temperature $\mathrm{CO}_{2}$ capture. The $\mathrm{CO}_{2}$ capture behavior on the porous $\mathrm{MgO}$ material involves a two-stage adsorption process which is not caused by adsorbed products, and the adsorption process is minimized by inter-particle diffusion resistance [24].

An intergovernmental panel on climate change (IPCC) report [25] on reduction of greenhouse gases (GHG) emissions indicated they could be lowered by adhering to two stringent processes: (i) by sequestering and capturing atmospheric $\mathrm{CO}_{2}$ or in coal power plants as produced $\mathrm{CO}_{2}$ and (ii) developing thermochemical energy storage systems using earth-abundant materials. Based on such high-level recommendations, our project addresses the fundamental and applied aspects of calcium-magnesium carbonates $\left[\mathrm{CaMg}\left(\mathrm{CO}_{3}\right)_{2}\right]$ or dolomites which have previously been shown to have potential in thermal energy storage applications [8,12,18-22]. The present study is the first examination of the thermochemical energy storage feasibility in high-dolomite phosphatic pebbles obtained from the Florida Industrial and Phosphate Research (FIPR) Institute that are quite abundant in Central Florida's phosphate mining sites. Besides the earth abundancy that makes the system cost effective, these calcium-magnesium carbonates or high dolomite pebbles possesses high enthalpy of reaction which is suitable for their wide usage in sustainable and green technological applications such as thermochemical energy storage (TCES) and carbon dioxide capture (Carbon Capture and Storage, CCS) [26-34].

\section{Applications of Dolomites in Concentrated Solar Power Plants (CSPs)}

Cheap, efficient, and non-toxic energy storage technologies are vital to handle the rapidly increasing usage of renewable energy at the power production plants, for example, grid stations, solar power plants and windmills. Solar energy-based power generation in concentrated solar power (CSP) plants often deploy phase change materials (PCMs) for storing the latent heat of the sun either received in parabolic troughs or dish-type configurations $[35,36]$. Another important method of storing heat is by thermochemical reactions using calcite and dolomite which undergoes reversible reactions of $\mathrm{CO}_{2}$ cycling at elevated temperatures $[37,38]$. The added advantage of using dolomites for such CSP applications can not only store the large amounts of energy per unit mass but it also can upgrade the temperature of the heat energy. The highest thermal $\mathrm{CO}_{2}$ conversion efficiency (above $50 \%$ ) is reported in these dolomite systems if the upgrading heat at $500{ }^{\circ} \mathrm{C}$ to temperatures above $800^{\circ} \mathrm{C}$ [37]. It has very recently demonstrated that the calcium looping $(\mathrm{CaL})$ process based on multicycle carbonation/calcination of natural limestone/dolomite for thermochemical storage of CSP [38].

\section{Experimental and Theoretical Methods}

\subsection{Materials Developed and Used}

Dolomite is $\sim 90 \%$ pure commercial naturally occurring mineral (grain sizes of $\sim 5 \mathrm{~mm}$ ) form has been procured from Alfa-Aesar and are labeled as CO-Dolo (commercial Dolomite). The handpicked dolomites with white color, pebbles were obtained from phosphate mining sites and are labeled as HP-Dolo (Hand Picked Dolomite). Both CO-Dolo and HP-Dolo are used as such with no further purification processes. The Retsch, PM 400, high energy ball milling under wet condition using DI water, was employed to process the handpicked dolomite, and are labeled as HP-Dolo-BM (Hand Picked Dolomite and Ball Milled). A Single-zone Tube Furnace (STF) from Carbolite is used for both the calcination (under $\mathrm{N}_{2}$ atmosphere) and carbonation (under $\mathrm{CO}_{2}$ ambient) and operate at temperature from $25^{\circ} \mathrm{C}$ up to $800{ }^{\circ} \mathrm{C}$ with ramping rate of $6^{\circ} \mathrm{C} / \mathrm{min}$. Two additional samples of both commercial and 
handpicked dolomites after their initial calcination stages were chosen and labeled as CO-Dolo-STF (Commercial Dolomite in Single Zone Tube Furnace) and HP-Dolo-STF (Hand Picked Dolomite in Single Zone Tube Furnace). All the samples were used completely in dry condition for characterization.

\subsection{Physicochemical Characterizations of Dolomites}

In general, multiple metrological and mineralogical techniques have been employed to characterize the different stages (plain commercial and handpicked dolomites and their calcined counterparts) of dolomite samples at room temperatures. Some of these techniques are powder X-ray diffraction, X-ray fluorescence, Fourier-Transform Infrared Spectroscopy (FTIR), automated scanning electron microscopy with energy dispersive $\mathrm{X}$-ray spectroscopy, thermogravimetric analysis, and BET surface area analysis. The experimental conditions of these techniques and the parameters used to study the dolomites are elaborated in detail in the following paragraphs.

A number of physicochemical characterizations have been carried out and the results are reported in terms of structural, microstructural, chemical, compositional, and thermal properties during calcination and subsequent carbonation reactions. The chemical composition, structural and microstructural characteristics of the dolomite minerals was studied using different techniques such as X-ray Fluorescence (XRF, Rigaku-NEX/QC/Quantez), Fourier-transform infrared spectroscopy (FTIR), and scanning electron microscopy with energy dispersive X-ray spectroscopy (SEM, EDS). All these metrological techniques confirmed the high percentage of dolomite mineral phase in the earth abundant phosphatic pebbles. The Fourier-Transform Infrared Spectra of the dolomite samples have been characterized using Agilent's CARY 600 FTIR spectrometer (Agilent Santa Clara, CA, USA). The Thermogravimetric analyzer (TGA/DSC 1, STAR ${ }^{\mathrm{e}}$ system), from Mettler Toledo (Columbus, $\mathrm{OH}, \mathrm{USA}$ ), was used to calculate the activation energy for calcination and carbonation of the dolomite pebbles in nitrogen $\left(\mathrm{N}_{2}\right)$ and carbon dioxide $\left(\mathrm{CO}_{2}\right)$ at temperatures up to $800^{\circ} \mathrm{C}$. The structural phase analysis of the dolomite minerals was observed using X-ray diffractometer (XRD) (Rigaku Mini Flex 600, Rigaku, Tokyo, Japan) with the parameters of $40 \mathrm{kV}$, current of $44 \mathrm{~mA}$, wavelength $(\lambda=1.540591 \AA)$ of X-ray beam corresponds to copper $\mathrm{K}_{\alpha}$ line, scan speed of $0.1001^{\circ} / \mathrm{min}$ and step width of $0.0100^{\circ}$. The ball-milling method was used to downsize (to micrometer size particles) the handpicked dolomite samples under DI water or another solvent medium. Not all the samples were milled before subjected to characterization techniques. Particle size and surface area were measured using XRD and $\mathrm{N}_{2}$ adsorption BET method (Quantachrome Instruments, Autosorb, Acquired by Anton Paar Quanta Tec Inc., Boynton Beach, FL, USA).

The commercial, handpicked, and ball-milled dolomite samples and their carbonated oxide phases via STF were analyzed using automated scanning electron microscopy (automated mineralogy tool manufactured by TESCAN, Brno, Czech Republic, at the Colorado School of Mines (CSM). Samples were loaded into the TESCAN (Automated SEM-EDX Mineralogy)-VEGA-3 Model LMU VP-SEM platform and analysis was initiated using the control program TIMA3. Four energy dispersive X-ray (EDX) spectrometers acquire spectra from each point or particle with a user defined beam stepping interval (i.e., spacing between acquisition points), an acceleration voltage of $25 \mathrm{keV}$, and a beam intensity of 14 . Interactions between the beam and the sample are modeled through Monte Carlo simulation. The EDX spectra are compared with spectra held in a look-up table allowing a mineral or phase assignment to be made at each acquisition point. The assignment makes no distinction between mineral species and amorphous grains of similar composition. TIMA software was deployed to study the semi-quantitative compositional mapping output results of dolomite minerals at different stages of calcination [39].

\subsection{Activation Energy Calculations}

Dynamic TGA was performed and analyzed according to ASTM E1641-16 [40] using the method of Ozawa, Flynn, and Wall [41]. The TGA decomposition curves of both CO-Dolo and HP-Dolo for several heating rates were analyzed using a general rate equation given as 


$$
\frac{d \alpha}{d T}=A(1-a) \exp \left[-E_{a} / R T\right] / \beta
$$

where $\alpha=$ fraction reacted, $A=$ pre-exponential factor, $\beta=$ heating rate $\left({ }^{\circ} \mathrm{C} / \mathrm{min}\right), E_{a}=$ activation energy $(\mathrm{J} / \mathrm{mole}), R=$ gas constant $(8.316 \mathrm{~J} /(\mathrm{mol} \mathrm{K})), T=$ absolute temperature $\left({ }^{\circ} \mathrm{C}\right)$, and $\mathrm{d} \alpha / \mathrm{dT}=$ rate of change of $\alpha$ with T. Using the method of Ozawa, Flynn, and Wall Equation (3) yields a relation for the activation energy given as

$$
E_{a}=\left(\frac{R}{b}\right) \frac{\Delta \log [\beta]}{\Delta\left[\frac{1}{T}\right]}
$$

Using a fixed decomposition fraction reaction (0.1, i.e., $10 \%$ decomposition), an initial activation energy was determined through the slope of a plot of the $\ln [\beta]$ versus $1 / T$ with an initial value of $b$ (constant assuming a first order reaction) of 0.457 (from the Doyle approximation). The activation energy was iteratively regressed until its value was constant and these are reported in the present work.

\section{Results and Discussion}

Sections 3.1 and 3.2 provide the semi-quantitative results based on the XRF and automated SEM-EDX analyses of plain and heat-treated dolomite minerals. Therefore, any correlations made on the compositional percentages are subjected to the limitations of the instrumental parameters and other underlying discrepancies.

\subsection{Chemical Make-Up via X-ray Fluorescence (XRF)}

The x-ray fluorescence characterization of CO-Dolo, HP-Dolo (see Figure 1) and their calcined counterparts were carried out to explore the chemical constituents in terms of bulk weight percentages. Table 1 below gives the compositional variations of these samples in terms of constituent compounds and their $w \mathrm{t} \%$. By reviewing the Table 1 , it is very clear that the HP-Dolo has the active content of $\mathrm{CaO}$ and $\mathrm{MgO}$ combined to be only $\sim 56 \%$, and the other $44 \%$ from inert compounds (e.g., $\mathrm{SiO}_{2} \sim 32 \%$ and $\mathrm{Al}_{2} \mathrm{O}_{3} \sim 7 \%$ ) which have no value added to the overall calcination and carbonation processes. Whereas, the CO-Dolo counterpart showed $\sim 88 \%$ of the mixtures of $\mathrm{CaO}$ and $\mathrm{MgO}$ that could fully contribute to the bi-metal carbonate $\left[\mathrm{CaMg}\left(\mathrm{CO}_{3}\right)_{2}\right]$ formation. Therefore, our further results of HP-Dolo samples with lower reported values in terms of percentage of mass conversion may be impacted due to their reported lower purity level. More remarks about the XRF are stated in Table 1.

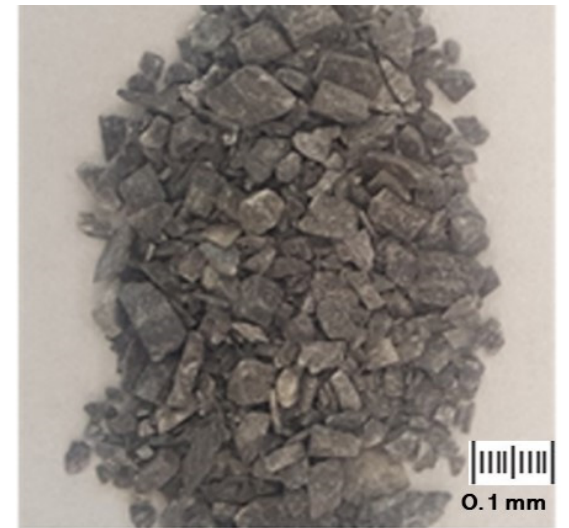

(a)

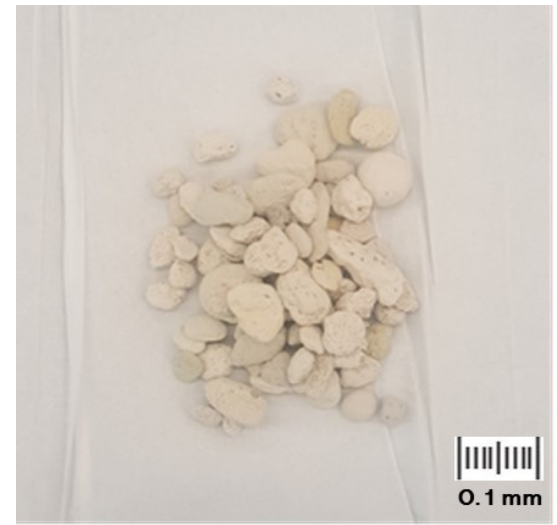

(b)

Figure 1. Snapshot camera pictures of (a) commercial dolomite sample; (b) handpicked dolomite sample. 
Table 1. X-ray Fluorescence data for both commercial and handpicked dolomites.

\begin{tabular}{|c|c|c|c|c|c|}
\hline $\begin{array}{l}\text { Elements or } \\
\text { Compounds }\end{array}$ & $\begin{array}{l}\text { CO-Dolo } \\
\text { wt } \%\end{array}$ & $\begin{array}{l}\text { CO-Dolo-STF } \\
\text { wt } \%\end{array}$ & $\begin{array}{l}\text { HP-Dolo } \\
\text { wt } \%\end{array}$ & $\begin{array}{l}\text { HP-Dolo-STF } \\
\text { wt } \%\end{array}$ & Remarks \\
\hline $\mathrm{CaO}$ & 67.90 & 34.26 & 36.60 & 32.00 & $\begin{array}{l}250 \% \text { reduction in } \mathrm{CaO} \text { content in } \mathrm{HP} \text {-Dolo. } \\
\text { After carbonation in STF, the } \mathrm{CaO} \text { content } \\
\text { increased in the range from } 3.5 \text { to } 17 \mathrm{wt} \%\end{array}$ \\
\hline $\mathrm{MgO}$ & 19.60 & 9.80 & 19.20 & 10.90 & $\begin{array}{l}\text { More or less equal amount of } \mathrm{MgO} \text { in both } \\
\text { samples. After carbonation in STF, } \\
\text { the } \mathrm{MgO} \text { content is reduced in the range } \\
\text { from } 1.7 \text { to } 8.3 \mathrm{wt} \%\end{array}$ \\
\hline $\mathrm{SiO}_{2}$ & 1.64 & 0.40 & 32.00 & 24.10 & $\begin{array}{l}\text { HP-Dolo contains large amount of silica } \\
\text { (sand type). After carbonation in STF, } \\
\text { the } \mathrm{SiO}_{2} \text { content reduced up to } 8 \mathrm{wt} \% \text {. }\end{array}$ \\
\hline $\mathrm{P}_{2} \mathrm{O}_{5}$ & 0.52 & 0.60 & 1.61 & 0.83 & $\mathrm{P}_{2} \mathrm{O}_{5}$ in trace amounts in all samples \\
\hline $\mathrm{Fe}_{2} \mathrm{O}_{3}$ & 9.94 & 9.33 & 2.53 & 3.88 & $\begin{array}{l}\mathrm{Fe}_{2} \mathrm{O}_{3} \text { is greater in CO-Dolo due to } \\
\text { purification procedures. }\end{array}$ \\
\hline $\mathrm{Al}_{2} \mathrm{O}_{3}$ & - & - & 6.66 & 5.07 & $\begin{array}{c}\text { Alumina } \mathrm{Al}_{2} \mathrm{O}_{3} \text { is found in Earth-mined } \\
\text { phosphates, HP-Dolo. }\end{array}$ \\
\hline $\begin{array}{l}\mathrm{CaO}+\mathrm{MgO} \\
\text { combined }\end{array}$ & 87.50 & 44.06 & 55.8 & 42.90 & $\begin{array}{l}\text { Added row } 1 \text { and row } 2 \text { values. } \\
\sim 30 \% \text { mass reduction in } \mathrm{HP} \text {-Dolo due to } \\
\text { unreactive } \mathrm{SiO}_{2} \text {. After carbonation in STF, } \\
\text { this reactive mixture of } \mathrm{CaO}+\mathrm{MgO} \\
\text { increased by } 3-8 \mathrm{wt} \% \text {. }\end{array}$ \\
\hline $\begin{array}{l}\text { Loss on } \\
\text { Ignition (LOI) }\end{array}$ & 0.00 & 45.00 & 0.00 & 22.00 & $\begin{array}{c}\text { Loss on Ignition is due to the } \mathrm{CO}_{2} \text { release } \\
\text { during calcination. }\end{array}$ \\
\hline
\end{tabular}

3.2. Compositional Mapping via Automated Scanning Electron Microscopy-Energy Dispersive X-ray Spectroscopy (SEM-EDX) Mineralogy

The XRF results as reported in Section 3.1 are at the elemental or compound $w t \%$ level. For example, we have given the $\mathrm{w} t \%$ of $\mathrm{CaO}$ and $\mathrm{MgO}$ and other oxide phases. The Loss on Ignition (LOI) correction is often needed while analyzing the $\mathrm{XRF}$, in order to account for the volatile compounds, in this case, $\mathrm{CO}_{2}$ locked in the dolomite $\left[\mathrm{CaMg}\left(\mathrm{CO}_{3}\right)_{2}\right]$ matrix [42,43]. Therefore, a sophisticated and automated mineralogical tool, Automated SEM-EDX Mineralogy with Variable Pressure-Scanning Electron Microscopy (VP-SEM) coupled with four energy dispersive X-rays (EDX) at the Colorado School of Mines was deployed to study the compositional mapping of all our samples listed in the experimental section and are tabulated in Table 2. Five different samples such as HP-Dolo, ball-milled HP-Dolo-BM, carbonated under nitrogen HP-Dolo-STFN2, carbonated under air HP-Dolo-STFO2 were studied for compositional mapping and are represented in Figure 2.

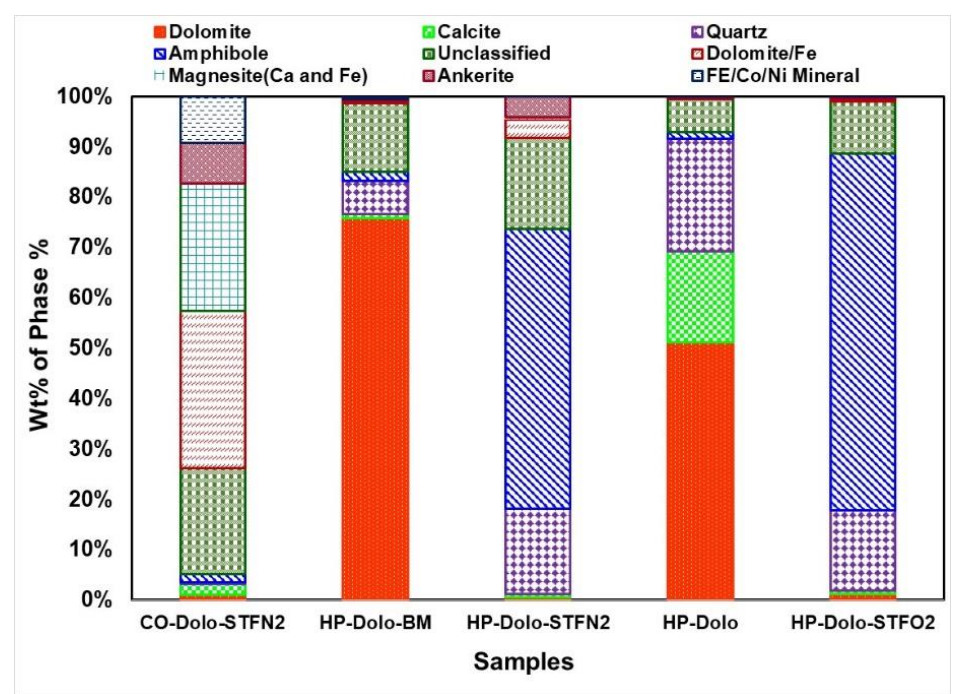

Figure 2. Automated Scanning Electron Microscopy-Energy Dispersive X-ray Spectroscopy (SEM-EDX) analysis of five different dolomite samples done at Colorado School of Mines (CSM). 
Table 2. Semi-quantitative results of samples under automated SEM-EDX Mineralogy (FP-SEM-EDX) at Colorado School of Mines.

\begin{tabular}{|c|c|c|c|}
\hline $\begin{array}{l}\text { Sample Category } \\
\text { Number(s) }\end{array}$ & Sample(s) Name & $\begin{array}{c}\text { Dolomite Pure or Dolomite (with Fe) } \\
\text { Concentration (as Reference Phase) } \\
\text { [wt } \% \text { of Phase } \%]\end{array}$ & $\begin{array}{c}\text { Other Major/Minor Phases } \\
\text { [wt } \% \text { of Phase } \%]\end{array}$ \\
\hline 1 & $\begin{array}{l}\text { Commercial + Hand } \\
\text { Crushed STF }\left(\mathrm{N}_{2} \text { ambient) }\right. \\
\text { [CO-Dolo-STFN2] }\end{array}$ & $\begin{array}{l}\text { Dolomite (Pure): } 0.91 \\
\text { Dolomite (with Fe): } 29.38\end{array}$ & $\begin{array}{l}\text { Magnesite (with } \mathrm{Ca} \text { and } \mathrm{Fe} \text { ): } 23.70 \\
\text { Magnesite (low } \mathrm{Ca} \text { and } \mathrm{Fe} \text { ) } 2.28 \\
\text { Ankerite (pure): } 7.56 \mathrm{Cr}-\mathrm{Ni} \\
\text { Ankerite: } 3.19 \\
\text { Calcite: } 2.09 \\
\text { Fe-Co-Ni Mineral: } 8.69 \\
\text { Quartz: 0.36 } \\
\text { Amphibole: } 1.46 \\
\text { Unclassified: } 19.74 \\
\text { Calcite: } 17.46\end{array}$ \\
\hline 2. & $\begin{array}{l}\text { Hand Picked + Hand } \\
\text { Crushed [HP-Dolo] }\end{array}$ & $\begin{array}{l}\text { Dolomite (Pure): } 49.60 \\
\text { Dolomite (with Fe): } 0.08\end{array}$ & $\begin{array}{l}\text { Quartz: } 21.67 \\
\text { Amphibole: } 1.26 \\
\text { Unclassified: } 6.36\end{array}$ \\
\hline 4 & $\begin{array}{l}\text { Hand Picked + Crushed STF } \\
\left(\mathrm{N}_{2} \text { ambient) }\right. \\
\text { [HP-Dolo-STFN2] }\end{array}$ & $\begin{array}{l}\text { Dolomite (Pure): } 0.50 \% \\
\text { Dolomite (with Fe): } 3.51\end{array}$ & $\begin{array}{l}\text { Quartz: } 15.98 \\
\text { Anorthite: } 4.42 \\
\text { Amphibole: } 51.93 \\
\text { Unclassified: } 16.92\end{array}$ \\
\hline 5 & $\begin{array}{l}\text { Hand Picked + Hand } \\
\text { Crushed STF (Air ambient) } \\
\text { [HP-Dolo-STFO2] }\end{array}$ & $\begin{array}{l}\text { Dolomite (Pure): } 1.15 \\
\text { Dolomite (with Fe): } 0.31\end{array}$ & $\begin{array}{l}\text { Ankerite: } 0.48 \\
\text { Quartz: } 14.26 \\
\text { Anorthite: } 8.01 \\
\text { Amphibole: } 63.47 \\
\text { Unclassified: } 9.33\end{array}$ \\
\hline
\end{tabular}

The commercial dolomite in its pristine stage was not examined in the Automated SEM-EDX Mineralogy measurements, but we have evaluated its partial carbonated version under STF $/ \mathrm{N}_{2}$ environment [CO-Dolo-STFN2]. This sample exhibits the majority of phases from the Fe-rich dolomite and magnesite and a few minority phases from Fe-Co-Ni minerals. Therefore, the CO-Dolo-STFN2, Automated SEM-EDX Mineralogy results are agreement with the higher concentration of $\mathrm{Fe}_{2} \mathrm{O}_{3}$ as previously demonstrated with the XRF results. Another interesting feature noticed based on the Table 2 and Figure 2 results is that the Fe-containing dolomite or Ankerite do occur in low concentration for both the commercial and handpicked samples. However, the Ankerite concentration increases, while heat treatment of these Fe containing dolomites which are commonly referred as Ferroan dolomite/Ankerite phases [44]. It is interesting to note that the quartz phase $\left(\mathrm{SiO}_{2}\right)$ is below $0.5 \%$, because of its removal while processing at the industrial scale. The Fe-free dolomite phase, up to $50 \%$, and calcite phase, up to $20 \%$, are predominantly seen in the HP-Dolo samples, which are handpicked at the phosphate mining site in the Central Florida region. At least $22 \%$ arises from the quartz, which is considered to be an inert material that does not contribute to the thermochemical reactions. The presence of such high concentrations of $\mathrm{SiO}_{2}$ in the earth-abundant dolomites, may lead for the de-agglomeration of particles resident during long-term thermal cycling; however, we have not validated this aspect experimentally.

The handpicked dolomite samples are now exposed to the ball milling in the presence of DI water [HP-Dolo-BM] at room temperature. This is carried out to enhance the dolomite reactive species, and to reduce the inert deadweight $\mathrm{SiO}_{2}$. To our surprise, these HP-Dolo-BM processed materials showed up to $75 \%$ of the pure dolomite phase and reduction of calcite to less than $1 \%$. It is unknown how the ball milling enhances the original sample $\mathrm{w} \mathrm{t} \%$ of HP-Dolo from $50 \%$ to HP-Dolo-BM, 75\% since it is theoretically not plausible. We hypothesize that the ball milling is a highly energy intensive mechanochemical process, with which the calcite phase from $17.5 \%$ (HP-Dolo) is fully consumed and that increases the concentration of pure dolomite phase. Another possible reason is the reduction of $\mathrm{SiO}_{2}$ from $22 \%$ to $6 \%$ after ball milling which increases the initial concentration of dolomite phase.

The handpicked dolomite samples were calcined in a single-zone tube furnace under nitrogen [HP-Dolo-STFN2] and oxygen (or air) [HP-Dolo-STFO2] atmospheres from $25^{\circ} \mathrm{C}$ to $800{ }^{\circ} \mathrm{C}$. This was 
to investigate the effect of the calcination process involving $\mathrm{CO}_{2}$ decomposition. It is observed that the initial dolomite phase of $49.6 \%$ and calcite phase of $17.5 \%$ was identified in the [HP-Dolo] samples and are considered to be the major contributing phases for thermal decomposition of $\mathrm{CO}_{2}$. Therefore, there is an increase of by-product Amphibole phase formation up to 52\% in [HP-Dolo-STFN2] and 63\% in [HP-Dolo-STFO2]. Approximately $4-8 \%$ of a minority satellite phase Anorthite was formed. There was a slight reduction of about $6 \%$ quartz phase between the handpicked dolomite sample and its calcined counterparts maybe due to inhomogeneities of the sample or measurement technique error. Moreover, the $\mathrm{SiO}_{2}$ characterization is of not much interest since this phase does not contribute for any thermochemical reactions, this quartz phase is considered to a dead weight and not further explored.

For samples 4 [HP-Dolo-STFN2] and 5 [HP-Dolo-STFO2], the $\mathrm{SiO}_{2}$ or quartz phase was identified by the Automated SEM-EDX Mineralogy are $15.975 \%$, and $14.26 \%$, respectively (please see Table 2). These mass percentages in close match with our XRF results as reported in Table 1, for the sample HP-Dolo-STF, the $\mathrm{SiO}_{2}$ phase is $\sim 24.1 \mathrm{wt} \%$. With this high concentration of $\mathrm{SiO}_{2}$ phase and the calcination of dolomites, the tube furnace ends up with Amphibole formation. On the other hand, for the non-calcined [HP-Dolo] sample, even though the $\mathrm{SiO}_{2}$ concentration of $21.67 \%$ (sample 2 in Table 2) and $32 \mathrm{wt} \%$ in Table 1, there was no Amphibole formation. Yet, another closer look of calcined commercial dolomite, sample 1 [CO-Dolo-STFN2], the Amphibole formation is less than $2 \mathrm{wt} \%$, due to the low concentration of $\mathrm{SiO}_{2}(0.36 \%)$. The same is true for the handpicked and ball milled sample 3 [HP-Dolo-BM], without further calcination, the Amphibole phase is less than $2 \%$ while the $\mathrm{SiO}_{2}$ is reported in Table 2, with $6.42 \%$. Based on the above analysis, it is very clear that, for the formation Amphibole phase, a sample composition parameter with a high concentration of $\mathrm{SiO}_{2}(>15 \mathrm{wt} \%)$, the sample must undergo high temperature calcination.

There is one unclassified phase which is universally present in all the samples, no matter whether this is in its pristine or calcined form, and this unclassified phase varies from $6 \%$ [HP-Dolo] to $20 \%$ [CO-Dolo]. Neither the ball milling nor the calcination of HP-Dolo increases the $w \mathrm{t} \%$ of this unclassified phase. Overall, the Automated SEM-EDX Mineralogy results have identified a number of possible phase compositions of dolomite and other related complex compounds in which the XRF has limited scope. The Automated SEM-EDX Mineralogy supplements and supports the XRF findings that the handpicked dolomites have an intrinsic impurity phase of $\mathrm{SiO}_{2}$ up to $20-30 \%$.

\subsection{Phase Determination and Crystallite Size Analysis via X-ray Diffraction (XRD)}

The X-ray diffraction was carried out for the three samples, namely, CO-Dolo, HP-Dolo and HP-Dolo-BM which is shown in Figure 3. The phase matching, peak and hkl planes identification was performed using ICSD database software, Version 4.4.0 that is loaded in the package of Rigaku, PDXL-2.

The commercial dolomite [CO-Dolo] exhibits a single phase compound with hkl indices matching $\mathrm{CaMg}\left(\mathrm{CO}_{3}\right)_{2}$, ICSD PDF Card no. 202162. There is one diffraction peak at $29.34^{\circ}$, d-value 3.026 that is assigned to the maximum intensity XRD peak of calcite (ICSD PDF Card No. 164935) with angle and d-values $\left(29.34^{\circ}, \mathrm{d}=3.042\right)$ matching with miller index correspond to $(104)$. On the other hand, the handpicked dolomite sample and its ball milled counterpart, showed $\mathrm{CaMg}\left(\mathrm{CO}_{3}\right)_{2}$ similar to the pristine dolomite, CO-Dolo sample. Since the pure dolomite mineral phases are predominant $(49.6 \%$-sample 2 and $74.9 \%$-sample 3$)$ than the Fe-containing dolomite phases $(0.08 \%$-sample 2 and $0.53 \%$-sample 3), as reported in Table 2; the XRD profiles show no indication of Fe in the dolomite structure. The Fe containing dolomite phase increase to $3.51 \%$ for calcined, handpicked dolomite (sample 4) and $29.38 \%$ for partially calcined, commercial dolomite (sample 1), for which the XRD was not performed. Additionally, an impurity phase, quartz $\left(\mathrm{SiO}_{2}\right)$ with ICSD PDF Card no. 42498 is matched with three diffraction peaks at $2 \theta$ angles of $27^{\circ}, 42^{\circ}$ and $69^{\circ}$, respectively. The relative intensities of the majority peak at $\sim 30.9^{\circ}$ is much smaller for the handpicked dolomites when compared to the commercial samples, thus indicating the handpicked versions are at the smaller average crystallite sizes. Table 3 represents the XRD data (few prominent peak positions) of all three samples mentioned 
above with respect to the shift in $2 \theta, \mathrm{d}$ spacing and full-width at half maximum (FWHM) values corresponding to the assigned dolomite phase with hkl Miller indices.

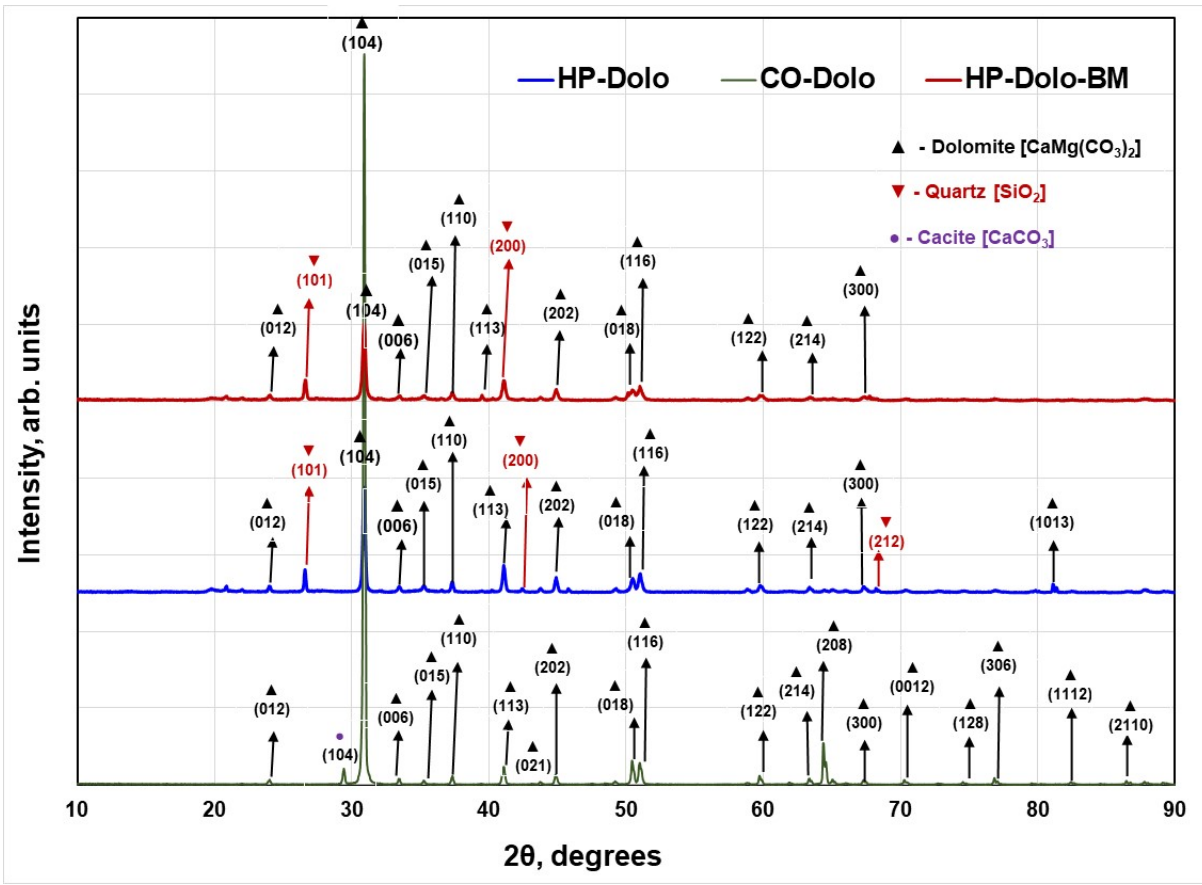

Figure 3. X-ray Diffraction (XRD) spectrum of commercial dolomite, handpicked dolomite, and ballmilled dolomite.

Table 3. Comparison of X-ray Diffraction (XRD) peaks of dolomite of Commercial Dolomite (CO-Dolo), Hand Picked Dolomite (HP-Dolo), and Hand Picked Dolomite and Ball Milled (HP-Dolo-BM).

\begin{tabular}{|c|c|c|c|c|c|c|c|c|c|}
\hline \multicolumn{3}{|c|}{ Co-Dolo } & \multicolumn{3}{|c|}{ HP-Dolo } & \multicolumn{3}{|c|}{ HPO-Dolo-BM } & Dolomite \\
\hline \multicolumn{3}{|c|}{$\begin{array}{l}\text { Average Crystallite } \\
\text { Size }=552.5 \mathrm{~nm}\end{array}$} & \multicolumn{3}{|c|}{$\begin{array}{c}\text { Average Crystallite } \\
\text { Size }=448.3 \mathrm{~nm}\end{array}$} & \multicolumn{3}{|c|}{$\begin{array}{l}\text { Average Crystallite } \\
\text { Size }=354.0 \mathrm{~nm}\end{array}$} & ICSD—202162 \\
\hline $2 \theta$ & d-value & FWMH & $2 \theta$ & d-value & FWHM & $2 \theta$ & d-value & FWHM & (hkl) \\
\hline 30.909 & 2.89075 & 0.1344 & 30.9 & 2.89125 & 0.188 & 30.906 & 2.89099 & 0.2253 & 104 \\
\hline 41.078 & 2.19557 & 0.1932 & 41.076 & 2.19565 & 0.1856 & 41.072 & 2.19588 & 0.2378 & 113 \\
\hline 44.841 & 2.01966 & 0.1696 & 44.878 & 2.01805 & 0.1829 & 44.868 & 2.01849 & 0.2226 & 202 \\
\hline 50.430 & 1.80814 & 0.1463 & 50.450 & 1.80746 & 0.2309 & 50.458 & 1.80721 & 0.2937 & 018 \\
\hline 50.982 & 1.78985 & 0.1809 & 51.008 & 1.7890 & 0.2195 & 51.005 & 1.78911 & 0.3062 & 116 \\
\hline \multicolumn{3}{|c|}{$\begin{array}{l}\text { Lattice Parameters (Calculated } \\
\text { for } h \mathrm{kl}=(300) \text { and }(006)) \\
\mathrm{a}=\mathrm{b}=4.8163(2) \AA \\
\mathrm{c}=16.0748(7) \AA \\
\text { Unit Cell Volume }=322.93(\AA)^{3}\end{array}$} & \multicolumn{3}{|c|}{$\begin{array}{l}\text { Lattice Parameters (Calculated } \\
\text { for } h \mathrm{kl}=(300) \text { and }(006)) \\
\mathrm{a}=\mathrm{b}=4.8146(5) \AA \\
\mathrm{c}=16.0504 \AA \\
\text { Unit Cell Volume }=322.22(\AA)^{3}\end{array}$} & \multicolumn{3}{|c|}{$\begin{array}{l}\text { Lattice Parameters (Calculated } \\
\text { for } h \mathrm{kl}=(300) \text { and }(006)) \\
\mathrm{a}=\mathrm{b}=4.8187(8) \AA \\
\mathrm{c}=16.0513 \AA \\
\text { Unit Cell Volume }=322.78(\AA)^{3}\end{array}$} & $\begin{array}{l}\mathrm{a}=\mathrm{b}=4.811 \AA \\
\mathrm{c}=16.0462 \AA \\
\text { Volume }=321.659(\AA)^{3}\end{array}$ \\
\hline
\end{tabular}

From Table 3, it is evident that the HP-Dolo samples show an increase in FWHM compared to the commercial dolomite sample, showing that the HP-Dolo has a less crystalline structure form when compared to the CO-Dolo sample. The handpicked ball milled samples on the other hand, have increased FWHM compared to their pristine, handpicked counterparts. This indicates a reduction in average crystallite sizes. The average crystallite sizes based on the Scherrer's equation is found to be $552.5 \mathrm{~nm}$ for CO-Dolo, $448.3 \mathrm{~nm}$ for HP-Dolo and $354 \mathrm{~nm}$ for HP-Dolo-BM. The FWHM shift in terms of the quartz phase has not been explored since this phase does not contribute for the thermochemical reactions during the calcination and carbonation processes.

The most useful information such as lattice constants and unit cell volume of these dolomite samples have been calculated and compared with PDF Card no. 202162 for $\mathrm{CaMg}\left(\mathrm{CO}_{3}\right)_{2}$. The crystal 
system with space group R-3:H(148) is adopted [45]. The lattice parameters ( $\mathrm{a}$ and c) and the unit cell volume of the commercial dolomite samples are slightly larger than the handpicked dolomites and it supports the average crystallites calculations. On the other hand, the ball milling though downsizes the crystallites about $94.3 \mathrm{~nm}$, the lattice constants, and the unit cell volume slightly higher in HP-Dolo-BM when compared to pristine HP-Dolo. This increase in both lattice parameters $\left(\Delta \mathrm{a} / \mathrm{a}_{0}=0.085 \% ; \Delta \mathrm{c} / \mathrm{c}_{0}=0.0056 \%\right)$ and unit cell volume $\left(\Delta \mathrm{V} / \mathrm{V}_{0}=0.18 \%\right)$ for the HP-Dolo-BM are due to the ball mill-induced deformation in the crystal lattice [46]. Additionally, since the ball milling was done in DI water and with only $10 \mathrm{~min}$, the possibility of Fe incorporation into the sample highly unlikely. The preciseness of the sample preparation and repeating of measurements are within the error limit of less than $1 \%$. Since the commercial and handpicked dolomite samples are as used without further purification the preciseness in preparation is almost $100 \%$. For the ball-milled, handpicked dolomites, we have followed same experimental conditions, such as ball to powder weight ratio, time duration and medium of milling; the preciseness of preparation is within $5 \%$ experimental and human error. The repeating of characterization measurements has been done with the standard operating procedure, so the preciseness was ensured, and it was within the error limit of less than $1 \%$.

\subsection{Chemical Environment via FTIR}

FTIR profiles of commercial dolomite (CO-Dolo), handpicked dolomite (HP-Dolo) and handpicked, ball-milled dolomite (HP-Dolo-BM) samples have been recorded for IR transmittance with wave numbers in the mid-IR region, ranging from 500 to $4000 \mathrm{~cm}^{-1}$ (see Figure 4). In general, the lower energy peaks, for example around 727, 876, 1023, 1418 and $1823 \mathrm{~cm}^{-1}$ matches with dolomite bands reported elsewhere $[47,48]$. The handpicked dolomites, both in its pristine and ball-milled stages, follow the same spectral trends as the commercial dolomites in the lower energy region. The dolomite stretch around $1023 \mathrm{~cm}^{-1}$ is, however, not prominently shown in the ball-milled HP-Dolo BM sample, whereas the sharpness of the $1418 \mathrm{~cm}^{-1}$ is increased. An additional peak around 2358 or $2362 \mathrm{~cm}^{-1}$ appears in the handpicked dolomite and its ball-milled counterpart, which indicates the stretch due to the quartz $\left(\mathrm{SiO}_{2}\right)$ phase [49] previously mentioned in the XRF, Automated SEM-EDX Mineralogy and XRD sections.

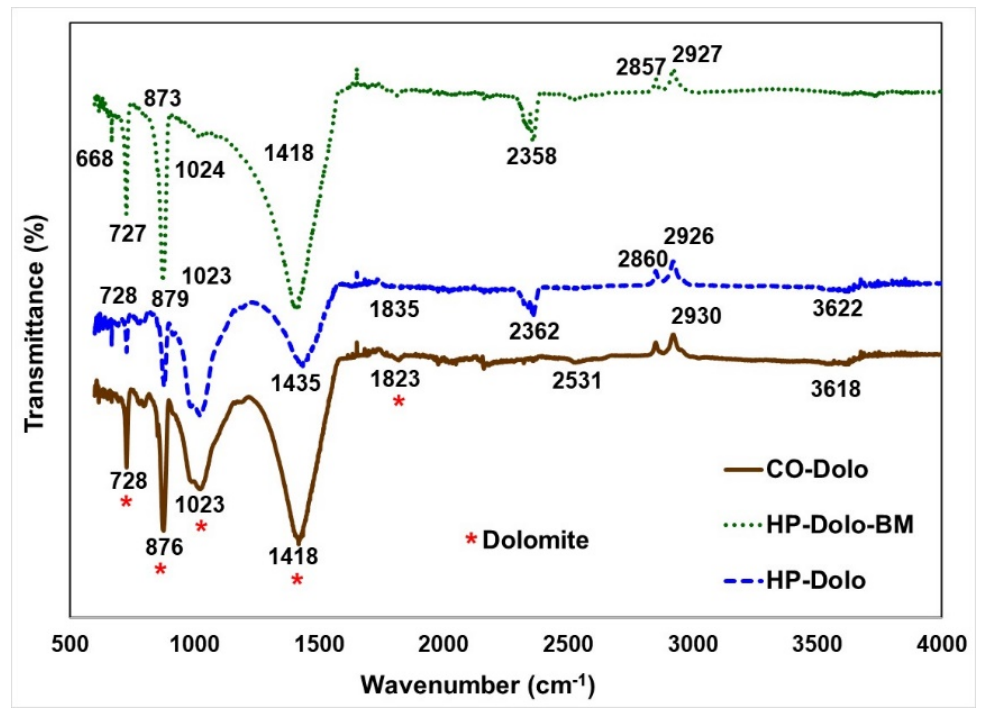

Figure 4. Fourier Transform Infrared (FTIR) spectra of CO-Dolo, HP-Dolo and HP-Dolo-BM samples in transmittance mode. 


\subsection{Surface Area via Brunanuer-Emmett-Teller (BET) Apparatus}

Since the calcination and carbonation involves solid-gas reactions, they are primarily surface based rather than bulk reactions. The surface area of the solid plays a vital role in locking and/or liberating the $\mathrm{CO}_{2}$ species from the dolomites at appropriate temperature- (calcination) and pressure-driven (carbonation) processes. Moreover, the amount of adsorbed gaseous nitrogen with monatomic layer is proportional to the surface area of the material. Figure 5 represents the 11-point BET (under liquid $\mathrm{N}_{2}$ ) after outgassing the materials at $300{ }^{\circ} \mathrm{C}$ for two hours.

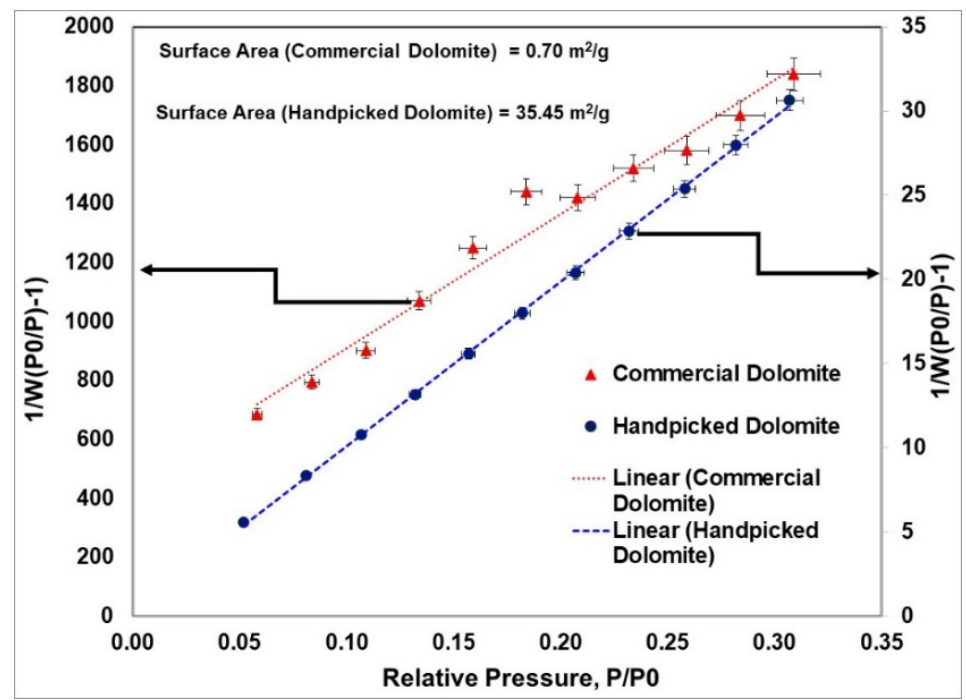

Figure 5. Brunanuer-Emmett-Teller (BET) surface area analysis of CO-Dolo and HP-Dolo samples in liquid $\mathrm{N}_{2}$.

Based on the BET analysis, we have determined the surface area which is approximately $35.45 \mathrm{~m}^{2} / \mathrm{g}$ for the handpicked dolomite, [HP-Dolo]. From the literature, pure calcium carbonate calcined at $745^{\circ} \mathrm{C}$ had a reported surface area of $15.2 \mathrm{~m}^{2} / \mathrm{g}$ [50] and the surface area of dolomite, from Carl Pool Co. 200+ mesh, is around $0.97 \mathrm{~m}^{2} / \mathrm{g}$ [51]. We have carried out the BET of the Alfa Aesar commercial dolomite sample, [CO-Dolo] and the surface area is found to be $0.7 \mathrm{~m}^{2} / \mathrm{g}$. Therefore, the higher surface area of HP-Dolo obtained from the BET measurements support the smaller crystallite size (increased FWHM) as evidenced from the XRD results in the Section 3.3.

\subsection{Activation Energy from Calcination via Thermogravimetric Analyzer (TGA)}

The TGA profiles of commercial dolomite (CO-Dolo) at different ramping rates of 2, 4, 6, 8, 10 and $20{ }^{\circ} \mathrm{C} / \mathrm{min}$ are shown in Figure 6a. Based on TGA kinetic profiles, the activation energy parameters for the calcination of the commercial dolomite sample is plotted in the inset of Figure $6 \mathrm{a}$ and the straight line determined by method ASTM 1641-16 [40] yielded the activation energy, Ea $=465 \mathrm{~kJ} / \mathrm{mol}$. For handpicked dolomite (HP-Dolo), a similar activation energy determined using different calcination ramping rates, is shown in Figure 6b. The HP-Dolo sample shows a lower activation energy of $323 \mathrm{~kJ} / \mathrm{mol}$ when compared to the commercial dolomite sample and thus, may be due to its secondary impurity phase, notably, $\mathrm{SiO}_{2}$. The tables below Figure $6 \mathrm{a}, \mathrm{b}$ denote the parametric values used based on the literature $[40,41]$. 

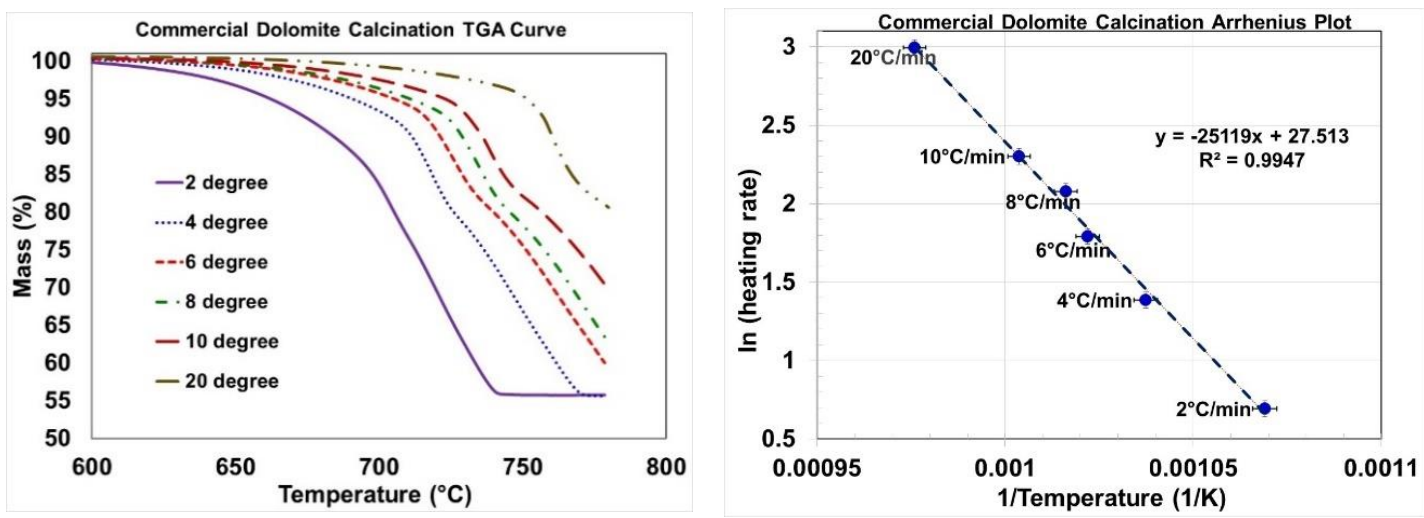

\begin{tabular}{|c|c|c|}
\hline dy/dx & -25.119 & $\mathrm{~K} / \mathrm{min}$ \\
\hline $\mathrm{R}$ & 8.316 & $\mathrm{~J} / \mathrm{molK}$ \\
\hline $\mathrm{Ea}^{*} \mathrm{~b}$ & 209 & $\mathrm{~kJ} / \mathrm{mol}$ \\
\hline $\mathrm{b}$ & 0.4495 & $\mathrm{k} / \mathrm{min}$ \\
\hline $\mathrm{Ea}$ & 465 & $\mathrm{~kJ} / \mathrm{mol}$ \\
\hline
\end{tabular}

(a)
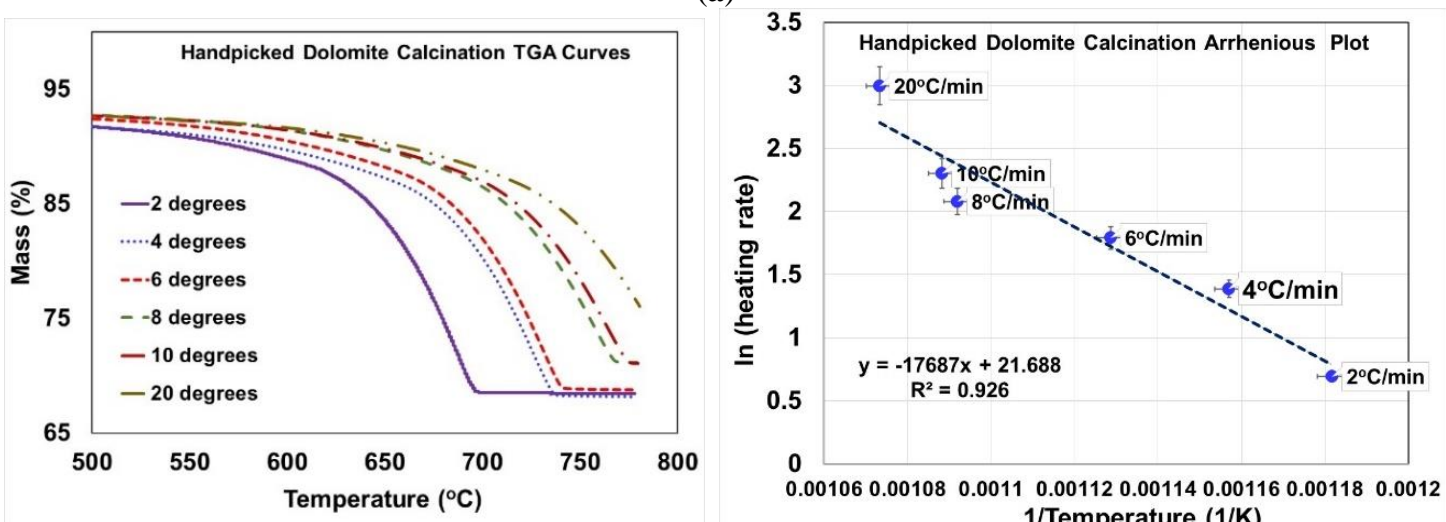

\begin{tabular}{|c|c|c|}
\hline $\mathrm{dy} / \mathrm{dx}$ & -17687 & $\mathrm{~K} / \mathrm{min}$ \\
\hline $\mathrm{R}$ & 8.316 & $\mathrm{~J} / \mathrm{molK}$ \\
\hline $\mathrm{Ea}^{*} \mathrm{~b}$ & 147 & $\mathrm{~kJ} / \mathrm{mol}$ \\
\hline $\mathrm{b}$ & 0.455 & $\mathrm{k} / \mathrm{min}$ \\
\hline $\mathrm{Ea}$ & 323 & $\mathrm{~kJ} / \mathrm{mol}$ \\
\hline
\end{tabular}

(b)

Figure 6. (a): TGA profiles (left) showing the calcination of commercial dolomite at different ramping rates, and the Arrhenius plot (right) based on Equation (3) [41]. (b): TGA profiles (left) showing the calcination of handpicked dolomite at different ramping rates, and the Arrhenius plot (right) based on Equation (3) [41].

\subsection{Activation Energy from Carbonation via TGA}

The effectiveness of the calcination process as reported in Section 3.6 was validated by the subsequent carbonation step under positive $\mathrm{CO}_{2}$ atmosphere in a single-zone tube furnace and the samples we have labeled as CO-Dolo-STFN2. The carbonation was also studied in TGA at temperatures up to $800^{\circ} \mathrm{C}$ under a flow of $\mathrm{CO}_{2}(100 \mathrm{~mL} / \mathrm{min})$ with different ramping rates $\left(2,4,6,8\right.$, and $\left.10^{\circ} \mathrm{C} / \mathrm{min}\right)$. Based on TGA kinetic profiles, the activation energy parameters for the carbonation of $\mathrm{CaO}$ and $\mathrm{MgO}$ to form $\mathrm{CaMg}\left(\mathrm{CO}_{3}\right)_{2}$, is plotted in the inset of Figure 7 and the straight line determined by ASTM 1641-16 [38] yielded the activation energy, $\mathrm{Ea}=38.7 \mathrm{~kJ} / \mathrm{mol}$. The activation energy of the handpicked dolomite was not performed due to poor carbonation and the lack of high pressure TGA. 


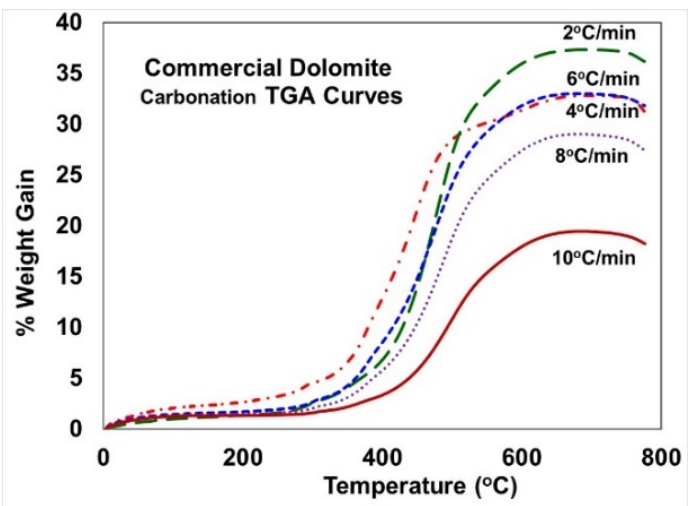

(a)

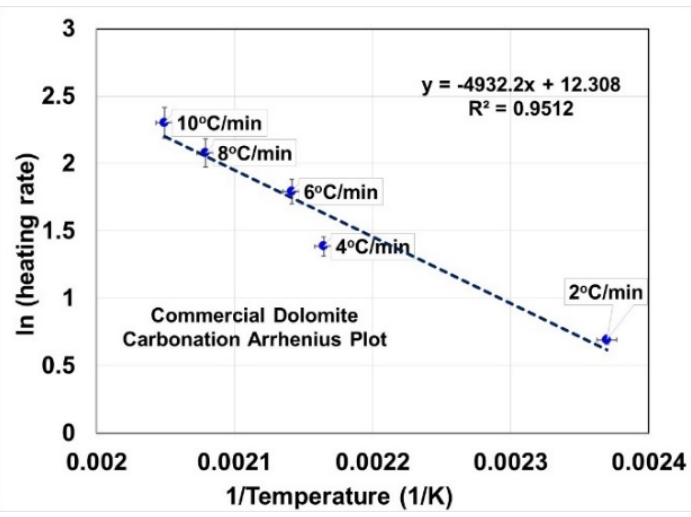

(b)

\begin{tabular}{|c|c|c|}
\hline $\mathrm{dy} / \mathrm{dx}$ & -4932 & $\mathrm{~K} / \mathrm{min}$ \\
\hline $\mathrm{R}$ & 8.316 & $\mathrm{~J} / \mathrm{molK}$ \\
\hline $\mathrm{Ea}^{*} \mathrm{~b}$ & 81.2421 & $\mathrm{~kJ} / \mathrm{mol}$ \\
\hline $\mathrm{b}$ & 0.4495 & $\mathrm{k} / \mathrm{min}$ \\
\hline $\mathrm{Ea}$ & 38.73659 & $\mathrm{~kJ} / \mathrm{mol}$ \\
\hline
\end{tabular}

Figure 7. TGA profiles (a) showing the carbonation of commercial dolomite at different ramping rates.

(b) The Arrhenius plot based on Equation (3) [41].

\subsection{Calcination-Carbonation Looping Cycle via TGA}

Cyclic stability in terms of the reversible calcination and carbonation reactions for the commercial, handpicked, and handpicked ball milled dolomite samples have been examined using thermogravimetric analysis. The TGA looping cycle methods were formulated to provide more than five continuous cycles for all the samples examined. Figure 8 demonstrates the continuous looping cycles with calcination under $\mathrm{N}_{2}$ up to $750^{\circ} \mathrm{C}$ at a heating rate of $10^{\circ} \mathrm{C} / \mathrm{min}$ and carbonation under $\mathrm{CO}_{2}$ up to $700^{\circ} \mathrm{C}$ at a heating rate of $10^{\circ} \mathrm{C} / \mathrm{min}$. with cooling in between the calcination-carbonation cycles.

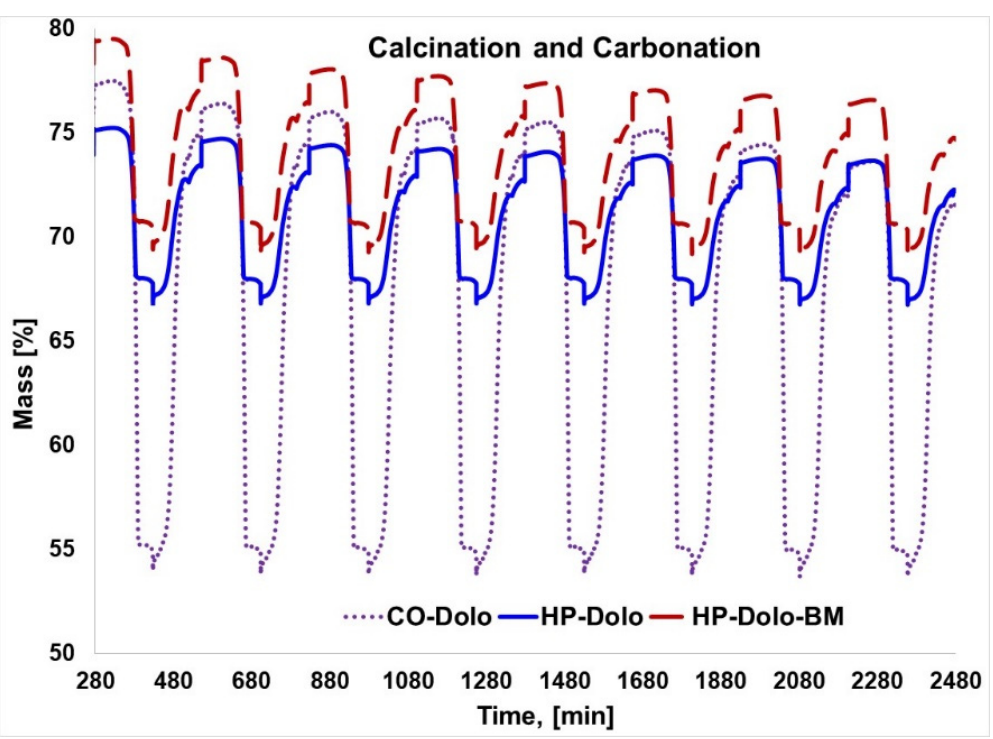

Figure 8. Calcination and carbonation looping cycles for dolomite samples including commercial (purple), handpicked (blue) and handpicked + ball milled (brown). 
All three samples showed good cyclic stability from the 2nd cycle onwards due to the absorption and release of $\mathrm{CO}_{2}$ as shown in Figure 8. T Compared to commercial dolomite samples, both handpicked and ball-milled samples showed less calcination and carbonation. It is obvious from the automated SEM-EDX Mineralogy, XRF and XRD analyses, that there is a presence of at least $30 \%$ of $\mathrm{SiO}_{2}$ in handpicked samples, which is inert to thermochemical reaction under $\mathrm{CO}_{2}$. The XRDs of the de- and re-carbonated samples during the life cycle measurements were not performed due to the limitation of sample size ( $<15 \mathrm{mg})$; however, we will execute such studies using a zero-background single-crystal $\mathrm{Si}$ sample holder, and the XRD results will be submitted for forthcoming publication.

\section{Conclusions}

It is concluded that the earth-abundant dolomite materials (handpicked dolomite, labeled as hp-dolo) as obtained from Central Florida's Phosphate Mines have demonstrated the energy storage behavior comparable to the commercial dolomite. The automated SEM-EDX Mineralogy and X-ray Fluorescence experiments were performed to obtain the quantitative measurements in terms of various mineral phases in dolomites during its various stages. The BET results the surface area of handpicked shows about $36 \mathrm{~m}^{2} / \mathrm{g}$ which is larger than the commercial samples. The XRD of handpicked samples showed two phases which included dolomite and impurity like quartz present. The lattice parameters, the unit cell volume and the average crystallite sizes of the handpicked dolomites are lower than the commercial materials because of its natural abundancy with no further purification, The FTIR spectra of all samples exhibit typical dolomite stretches as previously observed in the literature. The activation energy during calcination for both the commercial and handpicked dolomites, has been calculated using ASTM E1641-16 method. The carbonation activation energy for the commercial dolomite was lower in value compared to the calcination process. This may be due to the effect of positive $\mathrm{CO}_{2}$ pressure during the carbonation. The cyclic looping studies demonstrated stable cycling after the 2nd calcination-carbonation loop and continued for longer durations. Overall, the handpicked, Earth-abundant dolomites in its pristine, or ball milled powder form, are very comparable to the commercial dolomites, in terms of thermal energy storage, at high-temperature and -pressure conditions.

Author Contributions: Conceptualization, S.S. and J.D.; Data curation, S.L.W.; Formal analysis, M.B.J.C.; Funding acquisition, S.S.; Investigation, S.S.; Methodology, D.D.; Project administration, S.S. and G.A.; Resources, A.K.; Supervision, E.S.; Validation, G.R.C.; Writing-review and editing, S.S., S.L.W., N.H. and E.S. All authors have read and agreed to the published version of the manuscript.

Funding: This research was funded by Florida Industrial and Phosphate Research Institute (FIPR) and Florida Polytechnic University, grant number GR-18000010.

Acknowledgments: Authors are gratefully acknowledging the funding support from Florida Industrial and Phosphate Research Institute and Hinkley Center for Solid Waste Management. The automated SEM-EDX measurements support provided by Colorado School Mines, (Katherina Pfaff) is acknowledged. Florida Polytechnic University's Provost and Executive Vice President, Terry Parker is gratefully acknowledged for his institutional support to this project.

Conflicts of Interest: The authors declare no conflict of interest.

\section{Abbreviations}

$\begin{array}{ll}\mathrm{CaMg}\left(\mathrm{CO}_{3}\right)_{2} & \text { Calcium Magnesium Carbonate } \\ \text { FIPR } & \text { Florida Industrial Phosphate Research Institute } \\ \text { TCES } & \text { Thermochemical Energy Storage } \\ \text { XRF } & \text { X-ray Fluorescence } \\ \text { XRD } & \text { X-ray Diffraction } \\ \text { FTIR } & \text { Fourier-Transform Infrared Spectroscopy } \\ \text { Automated SEM-EDX } & \text { Manufacturing Company for Scanning Electron Microscopes to study Minerals } \\ \text { Mineralogy } & \text { Scanning Electron Microscopy } \\ \text { SEM } & \text { Energy Dispersive X-ray analysis } \\ \text { EDX } & \end{array}$




\begin{tabular}{|c|c|}
\hline BET & Brunauer-Emmett-Teller Surface Area Measurement Technique \\
\hline CSP & Concentrated Solar Power \\
\hline $\mathrm{CaCO}_{3}$ & Calcium Carbonate or Calcite \\
\hline $\mathrm{CaO}$ & Calcium Oxide \\
\hline $\mathrm{MgO}$ & Magnesium Oxide \\
\hline DAP & Diammonium Phosphate \\
\hline $\mathrm{MgSO}_{4} 7 \mathrm{H}_{2} \mathrm{O}$ & Magnesium Sulfate Heptahydrate \\
\hline $\mathrm{Al}_{2} \mathrm{O}_{3}$ & Aluminum Oxide or Alumina \\
\hline $\mathrm{SiO}_{2}$ & Silicon Dioxide or Silica \\
\hline $\mathrm{Fe}_{2} \mathrm{O}_{3}$ & Ferrous Oxide \\
\hline GW & Giga Watts \\
\hline $\mathrm{kWh}_{\mathrm{th}}$ & Kilo Watt Hour Thermal \\
\hline IPCC & Intergrovernmental Panel on Climate Chang (IPCC) \\
\hline CCS & Carbon Capture and Storage \\
\hline CO-Dolo & Commercial Dolomite (from Alfa Aesar) \\
\hline HP-Dolo & Handpicked Dolomite \\
\hline HP-Dolo-BM & Handpicked Dolomite and ball milled \\
\hline STF & Single-zone Tube Furnace \\
\hline CO-Dolo-STF & Commercial Dolomite Calcined in Single-zone Tube Furnace \\
\hline HP-Dolo-STF & Handpicked Dolomite Calcined in Single-zone Tube Furnace \\
\hline HP-Dolo-STFN2 & Handpicked Dolomite Calcined in Single-zone Tube Furnace under Nitrogen \\
\hline HP-Dolo-STFO2 & Handpicked Dolomite Calcined in Single-zone Tube Furnace under Oxygen or air \\
\hline $\mathrm{KBr}$ & Potassium Bromide \\
\hline TGA & Thermogravimetric Analyzer \\
\hline DSC & Differential Scanning Calorimetry \\
\hline ASTM & American Society for Testing and Materials \\
\hline CSM & Colorado School of Mines \\
\hline PDXL-2 & Powder X-ray Diffraction software \\
\hline ICSD PDF & Inorganic Crystal Structure Database Powder Diffraction File \\
\hline FWHM & Full Width at Half Maximum \\
\hline $\mathrm{kJ} / \mathrm{mol}$ & Kilo Joule per mole \\
\hline $\mathrm{J} / \mathrm{molK}$ & Joules per mole Kelvin \\
\hline
\end{tabular}

\section{References}

1. Van Kauwenbergh, S.J.; Cathcart, J.B.; McClellan, G.H. Minerology and Alteration of the Phosphate Deposits of Florida; U.S. Geological Survey Bulletin: Washington, DC, USA, 1914; pp. 1-56.

2. Garcia, M.; Davila, G.; Offeddu, D.; Soler, J.M.; Cama, J. Reactions during $\mathrm{CO}_{2}$ geological sequestration: Dissolution of calcite and dolomite coupled to gypsum precipitation. Rev. Soc. Esp. Mineral. 2011, 2, 93-94.

3. Loomis, F.B. Field Book of Common Rocks and Minerals; e-book; G.P. Putnam's Sons: New York, NY, USA; London, UK, 1948.

4. Bucher, K.; Frey, M. Definition, Conditions and Types of Metamorphism. In Petrogenesis of Metamorphic Rocks; Springer: Berlin/Heidelberg, Germany, 2002.

5. ITP Mining: Energy and Environmental Profile of the U.S. Mining Industry. December 2002. Available online: https:/www.energy.gov/eere/amo/downloads/itp-mining-energy-and-environmental-profile-usmining-industry-december-2002 (accessed on 23 September 2020).

6. DAP Quality Seminar Proceedings. 1986, pp. 1-45. Available online: http://fipr.state.fl.us/wp-content/ uploads/2014/12/01-000-041Final.pdf (accessed on 23 September 2020).

7. Good, P.; Zanganeh, G.; Ambrosetti, G.; Barbato, M.C.; Pedretti, A.; Steinfeld, A. Towards a commercial parabolic trough CSP system using air as heat transfer fluid. Energy Procedia 2014, 49, 381-385. [CrossRef]

8. Kakosimos, K.E.; Al-Haddad, G.; Sakellariou, K.G.; Pagkoura, C.; Konstandopoulos, A.G. Characterization of Qatar's Carbonates for $\mathrm{CO}_{2}$ capture and thermochemical energy storage. AIP Conf. Proc. 2017, 1850, 090003. 
9. Valverde, J.M.; Sanchez-Jimenez, P.E.; Perz-Maqueda, L.A. Ca-looping for postcombustion $\mathrm{CO}_{2}$ capture: A comparative analysis on the performances of dolomite and limestone. Appl. Energy 2015, 138, 202-215. [CrossRef]

10. Perejon, A.; Romeo, L.M.; Lara, Y.; Lisbona, P.; Martinez, A.; Valverde, J.M. The calcium-looping technology for $\mathrm{CO}_{2}$ capture: On the important roles of energy integration and sorbent behavior. Appl. Energy 2016, 162, 787-807. [CrossRef]

11. Benitez-Guerrero, M.; Valverde, J.M.; Sanchez-Jimenez, P.E.; Perejon, A.; Perez-Maqueda, L.A. Calciumlooping performance of mechanically modified $\mathrm{Al}_{2} \mathrm{O}_{3}-\mathrm{CaO}$ composites for energy storage and $\mathrm{CO}_{2}$ capture. Chem. Eng. J. 2018, 334, 2343-2355. [CrossRef]

12. Perlinger, J.A.; Almendiger, J.E.; Urban, N.R.; Eisenreich, S.J. Groundwater geochemistry of aquifer thermal energy storage long-term test cycle. Water Resour. Res. 1987, 23, 2215-2226. [CrossRef]

13. Rashad, M.M.; Baloumy, H.M. Chemical processing of dolomite associated with the phosphorites for production of magnesium sulfate heptahydrate. Eur. J. Miner. Process. Environ. Prot. 2005, 5, 174-183.

14. Santosh, G.; Andrew, M. Demonstration of High-Temperature Calcium-Based Thermochemical Energy Storage System for Use with Concentrating Solar Power Facilities. Sun Shot, U.S. Department of Energy, CSP Program Summit 2016, 16 Slides. Available online: https://www.energy.gov/sunshot (accessed on 23 September 2020).

15. International Energy Agency. IEA-ETSAP and IRENA(C) Technology Brief E17-January 2013; International Energy Agency: Paris, France, 2013.

16. FIPR 2011-2016 Strategic Plan; Energy and Environmental Profile of the US Mining Industry. Available online: https://www.fipr.state.fl.us/wp-content/uploads/2014/09/Strategic-Plan-2011-2016-v11_final-2014Poly-revision-final-for-Board-changes-accepted.pdf (accessed on 23 September 2020).

17. Warren, J. Dolomite: Occurrence, evolution and economically important assoications. Earth Sci. Rev. 2000, 52, 1-81. [CrossRef]

18. Belousouv, M.V.; Selivanov, E.N.; Gulyaeva, R.I.; Tyushnyakov, S.N.; Rakipov, D.F. Thermodynamics and kinetics of thermal dissociation of dolomite. Russ. J. Non-Ferr. Met. 2016, 57, 180-186. [CrossRef]

19. Valverde, J.M.; Sanchez-Jimenez, P.E.; Perez-Maqueda, L.A.; Quintanilla, M.A.S. Role of precalcination and regeneration conditions on postcombustion $\mathrm{CO}_{2}$ in the Ca-looping technology. Appl. Energy 2014, 125, 264-275. [CrossRef]

20. Olszak-Humienik, M.; Jablonski, M. Thermal behavior of natural dolomite. J. Therm. Anal. Calorim. 2015, 119, 2239-2248. [CrossRef]

21. Agrinier, P.; Deutsch, A.; Scharer, U.; Martinez, I. Fast back reactions of schock-released $\mathrm{CO}_{2}$ from carbonates: An experimental approach. Geochim. Cosmochim. Acata 2001, 65, 2615-2632. [CrossRef]

22. Latchman, D. Carbon Dioxide Capture from Fossil Fuel Power Plants Using Dolomite. Master's Thesis, University of South Florida, Tampa, FL, USA, 2010; 53p. Available online: https://scholarcommons.usf.edu/ etd/1693 (accessed on 23 September 2020).

23. Sayyah, M.; Lu, Y.; Masel, R.; Suslik, K.S. Mechanical Activation of CaO-Based Assorbents for $\mathrm{CO}_{2}$ capture. Chemsuschem 2013, 6, 193-198. [CrossRef]

24. Song, G.; Zhu, X.; Chen, R.; Liao, Q.; Ding, Y.-D.; Chen, L. An investigation of $\mathrm{CO}_{2}$ adsorption kinetics on porous magnesium oxide. Chem. Eng. J. 2016, 283, 175-183. [CrossRef]

25. De Coninck, H.C.; Loos, M.A.; Davidson, B.; Meyer, L.A. IPCC Special Report on Carbon Dioxide Capture and Storage; ECN-RX-05-209; Cambridge University Press: Cambridge, UK; New York, NY, USA, 2005; ISBN 0-521-68551-6.

26. Bayon, A.; Bader, R.; Jafarian, M.; Fedunik-Hofman, L.; Sun, Y.; Hinkley, J.; Miller, S.; Lipinski, W. Techno-economic assessment of solid-gas thermochemical energy storage systems for solar thermal power applications. Energy 2018, 149, 473-484. [CrossRef]

27. Humphries, T.D.; Moller, K.T.; Rickard, W.D.A.; Veronica Sofianos, M.; Liu, S.; Buckley, C.E.; Paskevicius, M. Dolomite: A low cost thermochemical energy storage material. J. Mater. Chem. A 2019, 7, 1206. [CrossRef]

28. Carrillo, A.J.; Gonzalez-Aguilar, J.; Romero, M.; Coronado, J.M. Solar energy on demand: A review on high temperature heat storage systems and materials. Chem. Rev. 2019, 119, 4777-4816. [CrossRef]

29. Moller, K.J.; Ibrahim, A.; Buckley, C.E.; Paskevicius, M. Inexpensive thermochemical energy storage utilizing additive enhanced limestone. J. Mater. Chem. A 2020, 8, 9646-9653. [CrossRef] 
30. Liu, M.; Steven Tay, N.H.; Bell, S.; Belusko, M.; Jacob, R.; Will, G.; Saman, W.; Bruno, F. Review on concentrating solar power plants and new developments in high temperature thermal energy storage technologies. Renew. Sustain. Energy Rev. 2016, 53, 1411-1432. [CrossRef]

31. Sarrion, B.; Valverde, J.M.; Perejon, A.; Perez-Maqueda, L.; Sanchez-Jimenez, E. On the multicycle activity of natural limestone/dolomite for thermochemical energy storage of concentrated solar power. Energy Technol. 2016, 4, 1013-1019. [CrossRef]

32. Reich, L.; Yue, L.; Bader, R.; Lipinski, W. Towards solar thermochemical carbon dioxide capture via calcium oxide looping: A review. Aerosol Air Qual. Res. 2014, 14, 500-514. [CrossRef]

33. Valverde, J.M.; Medina, S. Limestone calcination under calcium-looping conditions $\mathrm{CO}_{2}$ capture and thermochemical energy storage in the presence of $\mathrm{H}_{2} \mathrm{O}$ : An in situ XRD analyses. Phys. Chem. Chem. Phys. 2017, 19, 7587-7596. [CrossRef]

34. Medina-Carrasco, S.; Valverde, J.M. In situ XRD analysis of dolomite calcination under $\mathrm{CO}_{2}$ in a humid environment. CrystEngComm 2020. [CrossRef]

35. Goldfarb, L.; Sweigart, C.M. Heat Storage System. U.S. Patent No. 4,447,347, 8 May 1984.

36. Werner, S. Process of Producing Burnt Dolomite. U.S. Patent No. 2,380,480, 31 July 1945.

37. Alam, T.E. Experimental Investigation of Encapsulated Phase Change Materials for Thermal Energy Storage. Ph.D. Thesis, University of South Florida, Tampa, FL, USA, 2015; 112p. Available online: https://scholarcommons.usf.edu/etd/5632 (accessed on 23 September 2020).

38. Wickramarathne, C.; Moloney, F.; Pirasaci, T.; Kamal, R.; Goswami, D.Y.; Stefanakos, E.; Dhau, J. Experimental Study on Thermal Storage Performance of Cylindrically Encapsulated PCM in a cylindrical Storage Tank with Axial Flow. In Proceedings of the ASME 2016 Power Conference Collocated with the ASME 2016 10th International Conference on Energy Sustainability and the ASME 2016 14th International Conference on Fuel Cell Science, Engineering and Technology, Charlotte, NC, USA, 26-30 June 2016; ISBN 978-0-7918-5021-3. Paper No. POWER2016-59427, V001T06A014.

39. Honeyands, T.; Manuel, J.; Matthews, L.; O’Dea, D.; Pinson, D.; Leedham, J.; Zhang, G.; Li, H.; Monaghan, B.; Liu, X.; et al. Comparison of the mineralogy of iron ore sinters using of range of techniques. Minerals 2019, 9, 333. [CrossRef]

40. ASTM E1641-16. In Standard Test Method for Decomposition Kinetics by Thermogravimetry Using the Ozawa/Flynn/Wall Method; ASTM International: West Conshohocken, PA, USA, 2016.

41. Flynn, J.H.; Wall, L.A. A Quick, Direct Method for the Determination of Activation Energy from Thermogravimetric Data. Polym. Lett. 1966, 4, 323-328. [CrossRef]

42. Martin, A.L.; Inoue, H.; Yamada, Y.; Kohno, H. Sandardless XRF analysis for LOI-rich samples by scatter fundamental parameter method, Goldschmidt Conference Abstracts. Anal. Chem. 2005, p. A796. Available online: https://www.semanticscholar.org/paper/Standardless-XRF-analysis-for-LOI-rich-rock-samples-MartinInoue/07605bb3a20d5d76bacf6b9ff0b1669be35ec7a0\#paper-header (accessed on 23 September 2020).

43. King, B.-S.; Vivit, D. Loss on-ignition correction in the XRF analysis of silicate rocks. X-Ray Spectrom. 1988, 17, 4. [CrossRef]

44. Warne, S.S.J.; Morgan, D.J.; Milodowski, A.E. Thermal analysis studies of the dolomite, ferroan dolomite, ankerite series. Part 1. Iron content recognition and determination by variable atmosphere DTA. Thermochim. Acta 1981, 51, 105-111. [CrossRef]

45. Miser, D.E.; Swinnea, J.S.; Steinfink, H. TEM observations and X-ray crystal-structure refinement of a twinned dolomite with a modulated microstructure. Am. Mineral. 1987, 72, 188-193.

46. Sakher, E.; Loudjani, N.; Bechiheub, M.; Bououdina, M. Influence of milling time on structural and microstructural parameters of $\mathrm{Ni}_{50} \mathrm{Ti}_{50}$ prepared by mechanical alloying using Rietveld analysis. J. Nanomater. 2018, 2018, 1-11. [CrossRef]

47. Database of ATR-FT-IR Spectra of Various Materials, Dolomite in Mid-IR Region, Institute of Chemistry, University Tartu, Estonia. Available online: https://lisa.chem.ut.ee/IR_spectra/paint/fillers/dolomite/ (accessed on 23 September 2020).

48. Ji, J.; Ge, Y.; Balsam, W.; Damuth, J.E.; Chen, J. Rapid identification of dolomite using a Fourier Transform Infrared Spectrophotometer (FTR): A fast method for identifying Heinrich events in IODP site U1308. Mar. Geol. 2009, 258, 60-68. [CrossRef] 
49. Shokri, B.; Firouzjah, M.A.; Hosseini, S.I. FTIR Analysis of Silicon Dioxide Thin Film Deposited by Metal Organic-Based PECVD. Available online: https://www.ispc-conference.org/ispcproc/papers/791.pdf (accessed on 23 September 2020).

50. Chan, R.K.; Murthi, K.S.; Harrison, D. Thermogravimetric analysis of Ontario limestones and dolomites. II Reactivity of sulfur dioxide with calcined samples. Can. J. Chem. 1970, 48, 2979. [CrossRef]

51. Cui, L.; Ma, K.; Abdala, A.A.; Lu, L.J.; Tanakov, I.; Biswal, S.L.; Hirasaki, G.J. Adsorption of a switchable cationic surfactant on natural carbonate minerals. In Proceedings of the Society of Petroleum Engineers-19th SPE Improved Oil Recovery Symposium, IOR 2014, Tulsa, OK, USA, 12-16 April 2014; Society of Petroleum Engineers (SPE): Richardson, TX, USA, 2014; Volume 1, pp. 163-178.

(C) 2020 by the authors. Licensee MDPI, Basel, Switzerland. This article is an open access article distributed under the terms and conditions of the Creative Commons Attribution (CC BY) license (http://creativecommons.org/licenses/by/4.0/). 